\title{
ANALYSIS BY MEANS OF AN ANALOG COMPUTER OF PLASMA CORTICOID VALUES DURING ADRENOCORTICOTROPIC HORMONE INFUSION
}

\author{
By P. DE MOOR, W. DE BACKER, A. HENDRIKX, M. HINNEKENS, AND \\ A. DE BOCK \\ (From the Laboratory of Experimental Medicine of the Rega Institute, the Department \\ of Internal Medicine of the Saint Rafael Clinics, and the Laboratory for Electrical \\ Measurements and Electronics of the Physical Institute, University of \\ Louzain, Belgium)
}

(Submitted for publication December 11, 1959; accepted February 12, 1960)

Several parameters have been described by Samuels and his collaborators $(1-4)$ to evaluate cortisol metabolism. On the one hand, they utilize the intravenous administration of cortisol or other steroids for calculating the removal rate, the half-time and the apparent distribution volume of the injected substance. On the other hand, by the intravenous infusion of ACTH they obtain a convex curve of plasma concentrations of cortisol when they are plotted against time; they interpret this curve as being the result of two processes occurring simultaneously: $a$ ) a constant (maximal) adrenal production rate, and $b$ ) a constant removal of corticosteroids in direct proportion to the concentration at a given moment.

In order to calculate (maximal) adrenal production of cortisol, Samuels assumes the cortisol removal rate during ACTH infusion to be identical with the removal rate obtained after the intravenous administration of cortisol. This assumption however is at variance with other data from the same author. With the use of labeled cortisol he was able to show that the removal rate is dependent upon the initial cortisol level and that the values obtained with low initial cortisol levels were distinctly higher than the resultant figures after massive cortisol infusion.

In the present study ACTH and cortisol infusions were performed. By using an analog computer for analyzing the obtained data, it was possible to test in a direct way the hypotheses proposed by Samuels and associates. This instrument makes it possible to measure simultaneously the two determining constants of a differential equation. The parameters $p$ and $r$, as used by Samuels (and also in this paper) are relative rates, $p$ being expressed as micrograms per unit volume of blood per hour, $r$ meaning the percentage diminution in concentration relative to the concentration at the beginning of each consecutive time period (see Calculations).

\section{MATERIALS AND METHODS}

Subjects. The studies were performed on a) patients not suffering from endocrine, hepatic or renal diseases and who had previously not undergone treatment with ACTH or corticoids; b) patients with endocrine disorders or patients who had undergone endocrinological treatment; and c) patients with impairment of renal function. All of the subjects were hospitalized and were in the fasting state.

Cortisol disappearance rates and ACTH infusions. Cortisol and ACTH infusions were started at 8 a.m. \pm 15 minutes (morning experiments), at 8 p.m. \pm 15 minutes (evening experiments) and at midnight \pm 15 minutes (night experiments). A solution containing 0.02 per cent cortisol, 5 per cent glucose and 2 per cent alcohol was given intravenously over a period of 30 minutes. The total amount of cortisol administered was $1 \mathrm{mg}$ per $\mathrm{kg}$ of body weight. Blood was drawn immediately before the infusion, at 30 (end of the infusion), 60, 120, 180,240 and 300 minutes after the infusion was started. The disappearance rate of free plasma corticoids was calculated from the steroid concentration at these different periods, discarding the 30 -minute value.

A dose of 40 or 50 units of ACTH, dissolved in 500 $\mathrm{ml}$ of normal saline, was infused over a period of 8 hours. Blood samples were taken just before and at $1,2,3,4,6$ and 8 hours after the beginning of the infusion.

Heparinized blood samples were centrifuged within one hour upon withdrawal. Plasma samples were analyzed the same day blood was taken. All plasma corticoid values reported are the mean of duplicate determinations.

Method of assay. The dichloromethane extractable plasma corticosteroids were determined by a fluorimetric method described in detail elsewhere $(5,6)$. The general outline of the method is as follows. A 0.5 to $2 \mathrm{ml}$ sample of heparinized plasma is first extracted for 30 seconds with 3 to 6 volumes of petroleum ether. One and 
one-half $\mathrm{ml}$ of the original plasma sample is recovered and diluted with water to a final volume of $7.5 \mathrm{ml}$. This mixture is extracted once with $15 \mathrm{ml}$ of dichloromethane by gently inverting glass-stoppered extraction tubes 20 times. After centrifugation, about $12 \mathrm{ml}$ dichloromethane is separated and washed with $1 \mathrm{ml} 0.1$ $\mathrm{N}$ sodium hydroxide for 15 seconds. To $10 \mathrm{ml}$ of the final extract, corresponding to one-half of the initial plasma value, $2.5 \mathrm{ml}$ sulfuric acid-ethanol $(75: 25)$ is added. After mixing thoroughly for 15 seconds the dichloromethane is removed by aspiration. Secondary emitted light is measured exactly 5 minutes after mixing the dichloromethane extract with the sulfuric acid-ethanol mixture. A Photovolt (New York) fluorimeter with a $470 \mathrm{~m} \mu$ primary filter, a 540 (510 to 600) $\mathrm{m} \mu$ secondary filter and glass cells of $2.5 \mathrm{ml}$ was used throughout these studies. Reagent blanks amounted to 18 to 20 per cent of the $0.25 \mu \mathrm{g}$ cortisol fluorescence.

The method described proved to be reliable as judged by the criteria proposed by Borth (7). Precision was assessed on the basis of duplicate estimations at 4 different plasma steroid levels using final volumes of $1 \mathrm{ml}$ plasma. Standard deviations between duplicates were, respectively, 0.47 for a mean value of $5.1 \mu \mathrm{g}$ per $100 \mathrm{ml}$ (9.2 per cent), 0.50 for a mean value of $15.9 \mu \mathrm{g}$ per 100 $\mathrm{ml}$ (3.2 per cent), 0.72 for a mean value of $26.5 \mu \mathrm{g}$ per $100 \mathrm{ml}$ (2.7) and 1.72 for a mean value of $69.7 \mu \mathrm{g}$ per $100 \mathrm{ml}$ (2.5 per cent). All standard deviations have been calculated on at least 30 duplicate determinations. The smallest single result which, with some assurance, can be distinguished from zero is $0.94 \mu \mathrm{g}$ per $100 \mathrm{ml}$. The mean recovery of cortisol, $0.25,0.50$ or $1 \mu \mathrm{g}$ being added to 1 or $2 \mathrm{ml}$ plasma, was 101.4 per cent with a range from 96.5 to 107.3 per cent. The method is almost specific for cortisol, corticosterone and the $20 \beta$ hydroxy derivatives of these two steroids. Other steroids do not give much fluorescence in the experimental conditions used here. In Table I the number of galvanometric deflections obtained from several steroids is compared with that from cortisol. To a $20 \mathrm{ml}$ plasma sample, containing $20.4 \mu \mathrm{g}$ per $100 \mathrm{ml}$ fluorescent steroids, $2 \mu \mathrm{g}$ tritium-labeled cortisol was added. Specific activities were determined in quadruplicate before and after chromatography in a Bush-C system (8). It could be shown that 86.4 per cent of the initial fluorimertic value was due to cortisol.

In "normal" cases there exists a close correlation between the results obtained by this method and those obtained by the method of Peterson, Karrer and Guerra (9), the correlation coefficient being 0.89 . The "normal" 8 a.m. value for persons between 15 and 60 years is $21.9 \mu \mathrm{g} \pm 4.76$ cortisol equivalents per $100 \mathrm{ml}$. This figure includes a background of approximately $3 \mu \mathrm{g}$ per $100 \mathrm{ml}$. The individual day-to-day variation amounts to about 8 per cent; the variation between different individuals of the same age is about 20 per cent.

\section{CALCULATIONS}

The experimental results obtained from the ACTH tests were analyzed by an electronic analog computer.
TABLE I

Comparison of galvanometric deflections given by several steroids* at identical concentrations (25 $\mu \mathrm{g}$ per $100 \mathrm{ml})$

$\begin{array}{lc}\text { Cortisol } & 100 \\ \text { Corticosterone } & 50 \\ \text { 20 } \beta \text {-Hydroxy-cortisol } & 38 \\ \text { Cortisone } & 0 \\ \text { Tetrahydrocortisol } & 0.2 \\ \text { Tetrahydrocortisone } & 0.2 \\ \text { Prednisolone } & 0.6 \\ \text { Prednisone } & 0 \\ \text { Triamcinolone } & 0.4 \\ \text { Estriol } & 0.9 \\ \text { Estrone } & 0.2 \\ \text { Estradiol } & 1.3 \\ 9 \alpha \text {-Fluorocortisol } & 0\end{array}$

* Cortisol $(11 \beta, 17 \alpha, 21$-trihydroxy-4-pregnene-3, 20 dione); corticosterone (11 $\beta, 21$-dihydroxy-4-pregnene3, 20-dione); 20 $\beta$-hydroxy-cortisol $(11 \beta, 17 \alpha, 20 \beta, 21$ tetrahydroxy-4-pregnene-3-one); cortisone $(17 \alpha, 21$ dihydroxy-4-pregnene-3, 11, 20-trione); tetrahydrocortisol $(3 \alpha, 11 \beta, 17 \alpha, 21$-tetrahydroxy-pregnane-20-one); tetrahydrocortisone $(3 \alpha, 17 \alpha, 21$-trihydroxy-pregnane11, 20-dione); prednisolone $(11 \beta, 17 \alpha, 21$-trihydroxy

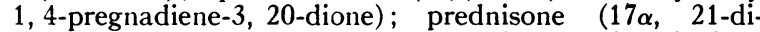
hydroxy 1, 4 pregnadiene-3, 11, 20-trione); triamcinolone ( $y \alpha$ fluoro, 11 $\beta, 16 \alpha, 17 \alpha, 21$-tetrahydroxy 1,4 pregnadiene, 3, 20-dione) ; estriol (1,3, 5(10)-estriene-3,16 $\alpha, 17 \beta$-triol); estrone (3-hydroxy-1, 3, 5(10) estriene-17-one); estradiol $(1,3,5(10)$-estriene-3, 17 $\beta$-diol) ; $9 \alpha$-fluorocortisol $(9 \alpha$ fluoro-11 $\beta, 17 \alpha, 21$-trihydroxy-4-pregnene-3, 20-dione).

The calculations were made on the assumption that the biological phenomena could be represented by the differential equation:

$$
\frac{d C}{d t}=p-r C
$$

where $\mathrm{C}=$ concentration of corticoids expressed as $\mu \mathrm{g}$ per $100 \mathrm{ml}$ plasma. $p=$ Production rate of corticoids by the adrenal cortex, expressed as $\mu \mathrm{g}$ per $100 \mathrm{ml}$ per hour. It is assumed that this production rate is constant throughout the infusion. $r=$ Removal rate of corticoids expressed as $1:$ hour. It is also assumed that this removal rate is constant.

The concentrations of corticoids were represented by electrical voltages and the biological relations were simulated by electronic means. In this way, a dynamic model of the described phenomenon was built up. The electronic diagram which was used is given in Figure 1. The constants $p$ and $r$ correspond to continuously variable potentiometer positions. The solution of the differential equation above was recorded with a cathode ray oscillograph. Changing the two potentiometers, $p$ and $r$ were adjusted until the solution of the equation proved to be completely identical with the experimental curve of corticoid concentration in function of time. In order to facilitate the operation, the experimental results were plotted according to an appropriate scale on a transparent paper which was attached to the screen of the oscillograph. The obtained values of $p$ and $r$ are classified according to the time the experiments were performed. From a statistical analysis, using $t$ tests, the 

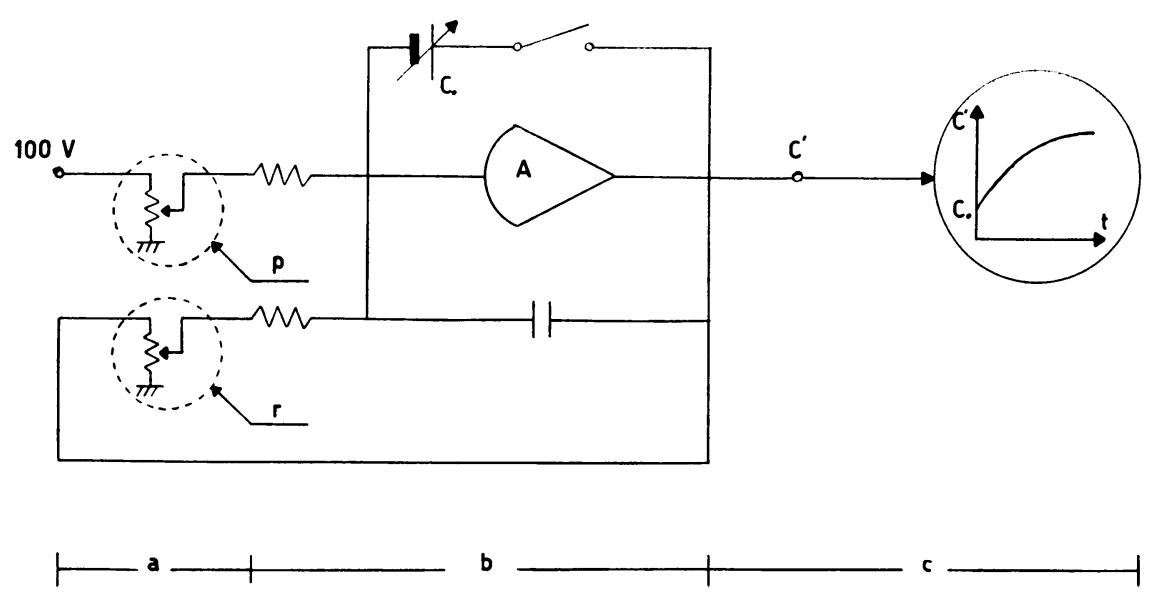

Fig. 1. Electronic schema of electronic analog computer. a = Potentiometer for adjusting of $p$ and $r ; \mathrm{b}=$ electronic operation amplifier circuit ; $\mathrm{c}=$ oscillograph.

following critical values (at $p=0.95$ ) were obtained for the significance of the differences $\Delta p, \Delta r$ and $\Delta(p: r)$.

I. ACTH infusion tests :

$$
\begin{aligned}
& \Delta p=8 \mu \mathrm{g} \text { per } 100 \mathrm{ml} \text { per hour } \\
& \Delta r=0.130 \\
& \Delta(p: r)=18 \mu \mathrm{g} \text { per } 100 \mathrm{ml} .
\end{aligned}
$$

II. Cortisol infusion tests:

$$
\Delta r=\left\{\begin{array}{l}
\text { morning-evening: } 0.047 \\
\text { morning-night: } 0.048 \\
\text { evening-night: } 0.032
\end{array}\right.
$$

\section{RESULTS}

A. Nonendocrine cases (Table II). The rate of disappearance of infused cortisol from the plasma was measured at 8 a.m. in 37 subjects, at 8 p.m. in 5 subjects and at midnight in 5 subjects. The half-time of cortisol in the plasma during the morning experiments was 142 minutes, during the evening experiments 148 minutes, and during the night experiments 174 minutes. These values correspond with a removal rate of $0.297,0.284$ and 0.242 , respectively. There is a significant difference between the morning and evening values on the one side and the night values on the other side.

ACTH was infused from 8 a.m. to 4 p.m. in 47 cases, from 8 p.m. to 4 a.m. in 24 cases and from midnight to 8 a.m. in 28 cases. A complete curve, i.e., constructed from 5 to 7 values, could be obtained in 42 out of the 47 morning experiments, in 23 out of the 24 evening experiments, and in 27 out of the night experiments. A total of 92 series of values was available. A graph of

\begin{tabular}{|c|c|c|c|c|c|c|}
\hline \multirow[b]{2}{*}{ Time of day } & & \multicolumn{3}{|c|}{ Men } & \multicolumn{2}{|c|}{ Women } \\
\hline & & & & Age & & \\
\hline \multirow{3}{*}{8 a.m. } & & $15-24$ & $25-59$ & 60 and over & $16-24$ & $25-59$ \\
\hline & $\begin{array}{l}\text { Max. production rate } \\
(\mu \mathrm{g} / \mathrm{ml} / \mathrm{hr})\end{array}$ & 26.5 & 21 & 33.5 & 17 & 24 \\
\hline & $\begin{array}{l}\text { Max. removal rate }(1 / \mathrm{hr}) \\
\text { No. of experiments }\end{array}$ & $\begin{array}{l}0.354 \\
4\end{array}$ & $12^{0.350}$ & $\begin{array}{l}0.390 \\
2\end{array}$ & $\begin{array}{l}0.230 \\
3\end{array}$ & $\begin{array}{l}0.390 \\
4\end{array}$ \\
\hline \multirow{2}{*}{8 p.m. } & $\begin{array}{l}\text { Max. production rate } \\
(\mu \mathrm{g} / \mathrm{ml} / \mathrm{hr})\end{array}$ & 21 & 23 & 17 & & 27 \\
\hline & $\begin{array}{l}\text { Max. removal rate }(1 / \mathrm{hr}) \\
\text { No. of experiments }\end{array}$ & $\begin{array}{l}0.500 \\
3\end{array}$ & $\begin{array}{l}0.520 \\
11\end{array}$ & $\begin{array}{l}0.405 \\
2\end{array}$ & & $\begin{array}{l}0.480 \\
1\end{array}$ \\
\hline \multirow{2}{*}{ Midnight } & $\begin{array}{l}\text { Max. production rate } \\
(\mu \mathrm{g} / \mathrm{ml} / \mathrm{hr})\end{array}$ & & 31 & 40.5 & & 30.5 \\
\hline & $\begin{array}{l}\text { Max. removal rate }(1 / \mathrm{hr}) \\
\text { No. of experiments }\end{array}$ & & $\begin{array}{l}0.510 \\
10\end{array}$ & $\begin{array}{l}0.800 \\
1\end{array}$ & & $\begin{array}{l}0.325 \\
2\end{array}$ \\
\hline
\end{tabular}
the mean values is shown in Figure 2.

TABLE II

Maximal production and removal rates obtained from ACTH infusions at different times of day 


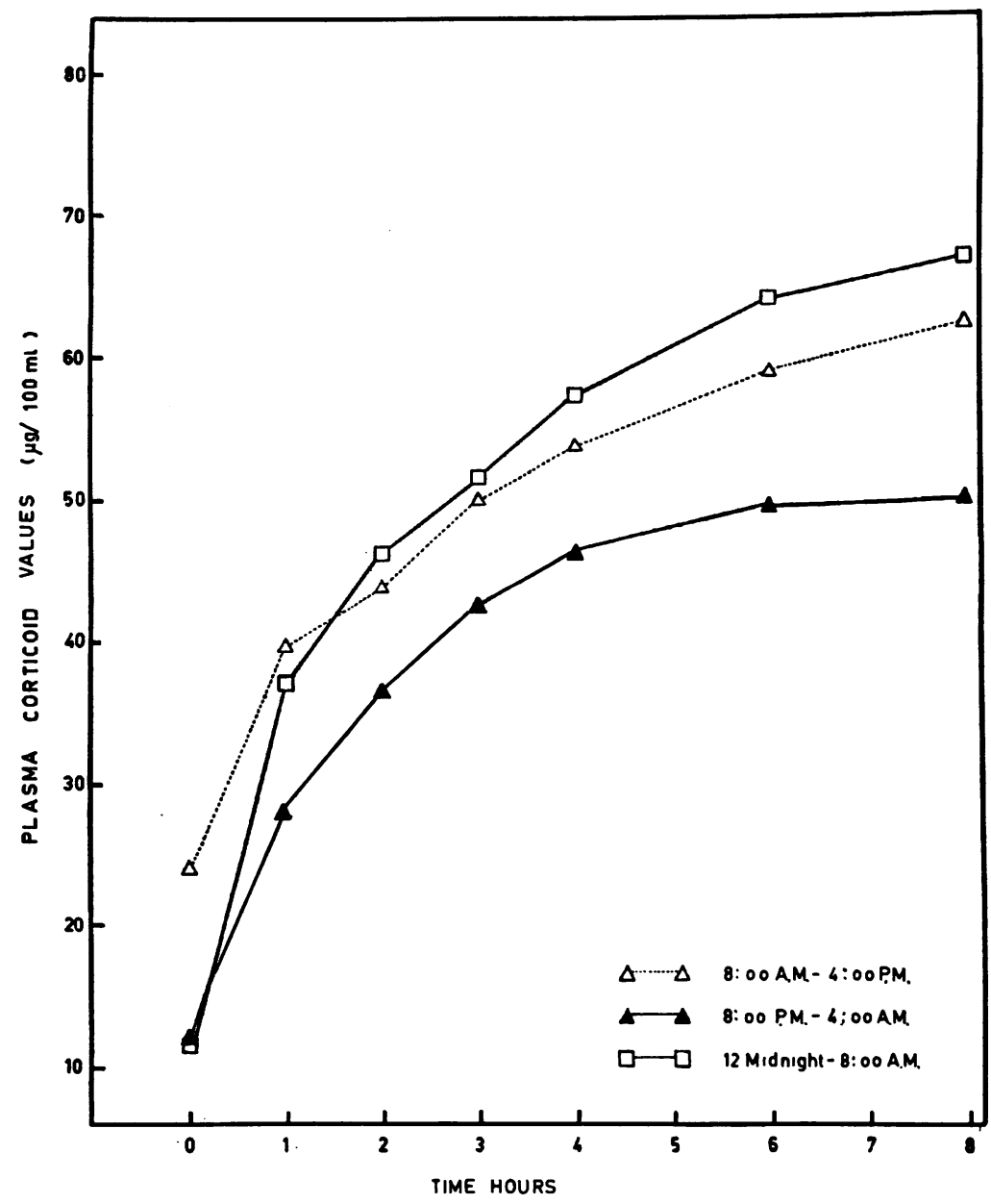

Fig. 2. Plasma corticoid Response to maximal stimulation with ACTH AT DIFFERENT TIMES OF DAY.

When analyzing the result yielded by the ana$\log$ computer, a constant rate of production $(p)$ and removal $(r)$ determining the experimental curve could be calculated in 55 out of the 92 tests. In 37 cases, however, different patterns were obtained. In 7 cases production and removal were not constant but decreased instead as the infusion progressed. Six of them were night ACTH tests and the seventh an evening test. Another kind of phenomenon observed was an increase of plasma corticoid concentrations above an arbitrary limit of $90 \mu \mathrm{g}$ per $100 \mathrm{ml}$. This occurred in 4 cases (in one of them, in addition, a decrease of production and removal as time progressed was observed) and also in 4 of the 55 cases in which production and removal were constant. Of these 8 cases of "corticoid concentration escape," 6 were night $\mathrm{ACTH}$ tests and 2 were evening tests. In a third aberrant group, consisting of 10 subjects, the corticoid concentration curve was composed of two convex segments; it appeared as though, after a first plateau was reached, a second curve was ascending to another plateau. There remained 17 tests which followed no definite pattern. The two last groups were equally divided over the morning, evening and night experiments.

$B$. Endocrine cases (Table III). In four instances of adrenogenital syndrome an average production rate of $7.6 \mu \mathrm{g}$ per $100 \mathrm{ml}$ per hour and an average removal rate of 0.015 was found. In two patients who had just finished a prolonged corticoid treatment (a minimum of $15 \mathrm{mg}$ prednisolone per day for at least one month), production was $9.5 \mu \mathrm{g}$ per $100 \mathrm{ml}$ per hour and removal 
TABLE III

Results of ACTH tests in some endocrine cases

\begin{tabular}{|c|c|c|c|c|c|c|c|c|c|}
\hline \multirow{3}{*}{$\begin{array}{l}\text { Subject } \\
\text { Age } \\
\text { Sex }\end{array}$} & \multirow[b]{3}{*}{ Diagnosis } & \multicolumn{5}{|c|}{$\begin{array}{l}\text { Plasma corticoid levels } \\
(\mu \mathrm{g} / 100 \mathrm{ml})\end{array}$} & \multicolumn{3}{|c|}{$\begin{array}{l}\text { Results obtained from } \\
\text { analog computer }\end{array}$} \\
\hline & & \multicolumn{5}{|c|}{ Hours } & \multirow{2}{*}{$\begin{array}{l}\text { Max. } \\
\text { produc- } \\
\text { tion rate }\end{array}$} & \multirow{2}{*}{$\begin{array}{c}\text { Max. } \\
\text { removal } \\
\text { rate }\end{array}$} & \multirow[b]{2}{*}{ SD } \\
\hline & & 0 & 2 & 4 & 6 & 8 & & & \\
\hline v.d. Br. & & & & & & & $\mu g / m l / h r$ & $1 / h r$ & \\
\hline $\begin{array}{c}30 \\
\wp\end{array}$ & Adrenogenital syndrome & 33 & 38.3 & 49.0 & 58.3 & 67.9 & 5 & 0 & \pm 1 \\
\hline $\begin{array}{l}\mathrm{V} \\
32 \\
+\end{array}$ & Adrenogenital syndrome & 23.8 & 34.9 & 40.9 & 49.9 & 68.5 & 5.6 & 0 & \pm 3 \\
\hline $\begin{array}{l}\text { VD } \\
46 \\
\wp\end{array}$ & Adrenogenital syndrome & 15.1 & 27.7 & 34.8 & 44.1 & & 10 & 0.060 & \pm 5 \\
\hline $\begin{array}{c}\mathrm{V} \\
16 \\
9\end{array}$ & Adrenogenital syndrome & 16.2 & 37.5 & 50 & 67.1 & & 10 & 0.030 & \pm 5 \\
\hline $\begin{array}{l}\mathrm{Di} \\
54 \\
\wp\end{array}$ & $\begin{array}{l}\text { Acromegaly, irradiation of } \\
\text { the hypophysis }\end{array}$ & 11.2 & 21.7 & 30.6 & 34.4 & 38.7 & 8 & 0.160 & \pm 2 \\
\hline $\begin{array}{c}\mathrm{S} \\
38 \\
\circ\end{array}$ & $\begin{array}{l}\text { Treatment with prednisone } \\
(15 \mathrm{mg} / \text { day) until } 3 \text { days } \\
\text { before experiment }\end{array}$ & 27 & 40.3 & 43.3 & 50.9 & 50 & 9 & 0.150 & \pm 5 \\
\hline $\begin{array}{l}Q \\
40 \\
\odot\end{array}$ & $\begin{array}{l}\text { Treatment with prednisone } \\
(15 \mathrm{mg} / \text { day) until } 3 \text { days } \\
\text { before experiment }\end{array}$ & 11.5 & 29.2 & 35.1 & 45.6 & 45.2 & 10 & 0.150 & \pm 4 \\
\hline
\end{tabular}

was 0.150 . These values were, respectively, 8 and $0.160 \mu \mathrm{g}$ per $100 \mathrm{ml}$ per hour in a patient with adenohypophyseal insufficiency.

C. Uremic patients. The clinical diagnoses and the results of the ACTH infusion tests are presented in Table IV.

\section{DISCUSSION}

Samuels and collaborators $(3,4)$ assume that the curves of plasma corticoid concentrations versus time obtained during $\mathrm{ACTH}$ infusions are the resultant of a constant rate of production and a constant rate of removal. When analyzing our results with the analog computer this could be confirmed in 55 out of the 92 tests. In the other 37 cases, however, different patterns were observed, as already mentioned in Results. In seven of them it was evident that production and removal decreased steadily with time and in the remaining cases this possibility could not be excluded.

TABLE IV

Results from ACTH tests in two patients with renal disease

\begin{tabular}{|c|c|c|c|c|c|c|c|c|c|c|c|}
\hline \multirow[b]{2}{*}{$\begin{array}{l}\text { Subject } \\
\text { Age } \\
\text { Sex }\end{array}$} & \multirow[b]{2}{*}{ Diagnosis } & \multicolumn{7}{|c|}{$\begin{array}{l}\text { Plasma corticoid levels } \\
(\mu \mathrm{g} / 100 \mathrm{ml})\end{array}$} & \multicolumn{3}{|c|}{$\begin{array}{l}\text { Results obtained from } \\
\text { analog computer }\end{array}$} \\
\hline & & & & & Hours & & & & $\begin{array}{l}\text { Max. } \\
\text { produc- } \\
\text { tion rate }\end{array}$ & $\begin{array}{l}\text { Max. } \\
\text { removal } \\
\text { rate }\end{array}$ & SD \\
\hline $\begin{array}{c}M \\
27 \\
9\end{array}$ & $\begin{array}{l}\text { Chronic pyelonephritis } \\
\text { +uremia (serum urea: } \\
236 \mathrm{mg} / 100 \mathrm{ml})\end{array}$ & $\begin{array}{c}o \\
13.1\end{array}$ & $\begin{array}{c}1 \\
27.7\end{array}$ & $\begin{array}{c}2 \\
33.1\end{array}$ & $\begin{array}{c}3 \\
39.6\end{array}$ & $\begin{array}{c}4 \\
49.0\end{array}$ & $\begin{array}{c}6 \\
56.2\end{array}$ & $\begin{array}{c}8 \\
57.7\end{array}$ & $\begin{array}{c}\mu g / m l / h r \\
18.7\end{array}$ & $\begin{array}{c}1 / h r \\
0.300\end{array}$ & \pm 5 \\
\hline $\begin{array}{l}\mathrm{V} \\
56 \\
\sigma^{7}\end{array}$ & $\begin{array}{l}\text { Diabetes, nephrosclerosis } \\
+ \text { uremia (serum urea: } \\
90 \mathrm{mg} / 100 \mathrm{ml} \text { ) }\end{array}$ & 25.3 & 45.6 & 51.8 & 58.8 & 61.4 & 68.0 & 71.3 & 30 & 0.430 & \pm 3 \\
\hline
\end{tabular}


TABLE V

Diurnal variation in corticoid metabolism*

\begin{tabular}{|c|c|c|c|c|c|c|c|c|}
\hline & \multicolumn{4}{|c|}{ Perkoff $e t$ al. (14) } & \multicolumn{4}{|c|}{ Present results } \\
\hline \multirow{2}{*}{$\begin{array}{l}\text { Plasma corti- } \\
\text { coid values } \\
(\mu \mathrm{g} / 100 \mathrm{ml})\end{array}$} & $\begin{array}{l}8 \text { a.m. } \\
16.02\end{array}$ & $\begin{array}{l}4 \text { p.m. } \\
11.12\end{array}$ & $\begin{array}{l}8 p . m . \\
7.42\end{array}$ & $\begin{array}{l}\text { midnight } \\
7.42\end{array}$ & $\begin{array}{c}8 \text { a.m. } \\
21.90 \pm 1.4 \%\end{array}$ & $\begin{array}{c}4 \text { p.m. } \\
12.29 \pm 5 \%\end{array}$ & $\begin{array}{c}8 p . m . \\
11.90 \pm 10 \%\end{array}$ & $\begin{array}{c}\text { midnight } \\
11.50 \pm 15 \%\end{array}$ \\
\hline & {$[51]$} & {$[51]$} & {$[51]$} & {$[51]$} & {$[250]$} & {$[36]$} & {$[36]$} & {$[36]$} \\
\hline \multirow{2}{*}{$\begin{array}{l}\text { Maximum pro- } \\
\text { duction rate } \\
(\mu \mathrm{g} / 100 \mathrm{ml} / \mathrm{hr})\end{array}$} & 16.00 & 16.00 & & 14.00 & $22.90 \pm 8 \%$ & & $24.40 \pm 9 \%$ & $31.90 \pm 4 \%$ \\
\hline & {$[5]$} & {$[4]$} & & [6] & {$[25]$} & & {$[17]$} & {$[13]$} \\
\hline \multirow{2}{*}{$\begin{array}{l}\text { Maximum "ACTH" } \\
\text { removal rate } \\
(1 / \mathrm{hr})\end{array}$} & 0.359 & 0.252 & & 0.525 & $0.347 \pm 8 \%$ & & $0.497 \pm 7 \%$ & $0.503 \pm 9 \%$ \\
\hline & [5] & {$[4]$} & & {$[6]$} & {$[25]$} & & {$[17]$} & [13] \\
\hline \multirow{2}{*}{$\begin{array}{l}\text { Cortisol infusion } \\
\text { removal rate } \\
(1 / \mathrm{hr})\end{array}$} & 0.318 & 0.315 & & 0.311 & $0.297 \pm 3 \%$ & & $0.284 \pm 3 \%$ & $0.242 \pm 5 \%$ \\
\hline & {$[6]$} & {$[6]$} & & {$[4]$} & [37] & & {$[5]$} & [5] \\
\hline
\end{tabular}

* Figures in [] indicate number of experiments. The experimental results of Perkoff have been recalculated by means of the analog computer. The \% figures give the standard deviations of mean as per cent of mean.

Removal rates and zero time intercepts obtained after intravenous administration of cortisol have been used by other authors (4) for estimating (maximal) production rate during ACTH infusion. However, from the data presented in this study, it appears that this assumption is not valid. By means of the analog computer, production and removal rates could be calculated independently. The removal rates obtained in this way from ACTH infusion data were consistently greater than were the removal rates after cortisol infusion. The difference in the means, although not significant in the morning tests ( 0.347 versus $0.297)$, becomes significant for the night tests $(0.503$ versus 0.242$)$. On the other hand, if one puts removal rates obtained after cortisol infusion into the analog computer, the instrument is not able to find a production rate to cover the experimental ACTH curve.

Removal of cortisol from the plasma can occur through the kidneys, and is usually negligible (10); by extravascular diffusion and binding of the hormone in certain tissues (11) ; and by metabolism and partial destruction of the hormone in the liver (liver removal) (12). It is not surprising that the removal rate during ACTH stimulation is larger than the removal rate after cortisol infusion if one considers what happens during these tests. After infusion of cortisol ( $1 \mathrm{mg}$ per $\mathrm{kg}$ ) there is at first preponderantly an extravascular diffusion. At the end of the infusion, almost 95 per cent of the administered hormone has already disappeared from the plasma compartment. The apparent distribution volume, small initially, has expanded maximally. But after about one hour a steady state has been reached and thereafter a constant removal rate prevails during the following four to six hours. It is generally accepted that at this time liver removal plays a predominant role (4). A different situation, however, is encountered during ACTH infusion. Here small amounts of cortisol are constantly delivered into the blood stream. Diffusion and liver removal take place simultaneously (13) and the observed "ACTH" removal rate as the result of both processes has to be greater than the removal rate after cortisol infusion.

The results from this study can be compared with those of Perkoff and associates (14), who also performed ACTH and cortisol infusions at different times of the day (Table V). As to the diurnal variation in plasma corticoid concentration, the figures obtained from both studies are equal except that the fluorimetric values are about $5 \mu \mathrm{g}$ per $100 \mathrm{ml}$ higher than those obtained by the colorimetric method. In order to compare Perkoff's production and removal values with ours, his data have been recalculated by the analog computer. As can be seen from Table V, practically the same values for production rate were found for the morning and evening ACTH infusions; the small difference observed in our study does not appear to be significant on statistical analysis. It should be mentioned that the even- 
ing tests of l'erkoff started at 4 p.m. whereas ours were begun at 8 p.m. The maximal production rates calculated from the night tests, however, are quite different; here, instead of lower values, significantly higher values than during the morning or evening experiments were obtained. The removal rates during the morning and night ACTH tests are almost identical in both studies, but for the evening experiments our figures are much greater (Table V).

In an attempt to explain these differences in removal rate at evening and production rate at midnight, several possibilities may be considered. Difference in sex could eventually be held responsible for the observed phenomena. The data from our study do not exclude this possibility; in fact, all evening and night ACTH experiments were performed on male subjects (Table II). The time at which the experiments were performed should also be considered since as already mentioned, the evening experiments of Perkoff started at 4 p.m. whereas our started at 8 p.m. Furthermore, it should be taken into account that different dosage technics and group reactions have been used. Whereas the colorimetric procedure of Porter and Silber, used by Perkoff (14), estimates cortisol, cortisone, Compound $\mathrm{S}$ of Reichstein and the $\mathrm{H}_{2}$ and $\mathrm{H}_{4}$ derivatives of these steroids, the fluorimetric procedure used in our study measures cortisol, corticosterone and Compound $U$ of Reichstein. Our finding of a greater production capacity at midnight could have been caused by an increase in corticosterone production or a conversion of cortisol and corticosterone to $20 \beta$-hydroxy derivatives. The difference in evening removal rates could be analagously explained.

In contrast with the findings of others (14), the maximal liver removal obtained by cortisol infusion did not remain constant throughout the day.

From data concerning production and removal rates during $\mathrm{ACTH}$ infusion conclusions regarding diurnal variation in corticoid metabolism have been made. It would appear to us, however, that such a concept is of questionable value. Maximal rate of production and removal as obtained from infusion of high doses of ACTH is not the same as real production and removal rate of cortisol. Also it should be realized that even if apparent maximal clistribution volume remains constant throughout the day, this does not necessarily mean that the real volume of distribution and, consequently, the distribution removal, are fixed parameters throughout the day.

When analyzing further the figures of rate of production and removal during $\mathrm{ACTH}$ infusion, it appears that the ratio $p$ maximum $: r$ maximum from the morning experiments is equal to that from the night experiments: $68.1 \pm 5$ per cent at morning versus $68.5 \pm 10$ per cent at night. This ratio can also be expressed as the " $\mathrm{C}$ plateau" which means the concentration of plasma cortisol at which the ACTH curve has attained a steady state and will remain so with time. Attention should be drawn to the fact that although the ratio $p$ maximum: $r$ maximum is the same for the morning and night experiments, the absolute values of production rate and removal rate are greater at night than during the morning. Also, it is in the group of night experiments that the majority of production and removal values, not remaining constant, or both becoming less with time, are found. Whether this is due to a change from a steady state on a high plateau (midnight) to a steady state on a lower plateau (morning) cannot be judged at this time. In regard to the $p$ maximum: $r$ maximum ratio for the evening experiments, a much smaller value $(51.5 \pm 10$ per cent) is obtained, the difference with the morning and night values being statistically significant.

In order to explore the $p$ maximum : $r$ maximum ratio further, the rates of production and removal, obtained from morning ACTH tests in normal and in some endocrine patients, are plotted against each other in Figure 3. From the data presented it appears this ratio is a kind of bioconstant, in which adjustments in production and removal are operating to maintain its value. This ratio also shows a diurnal variation.

\section{SUMMARY}

Cortisol and ACTH were administered intravenously to patients suffering from diseases not involving the endocrine system nor from endocrine or renal diseases. Blood was drawn at intervals, and dichloromethane-extractable plasma corticoids were measured by a fluorimetric method. 


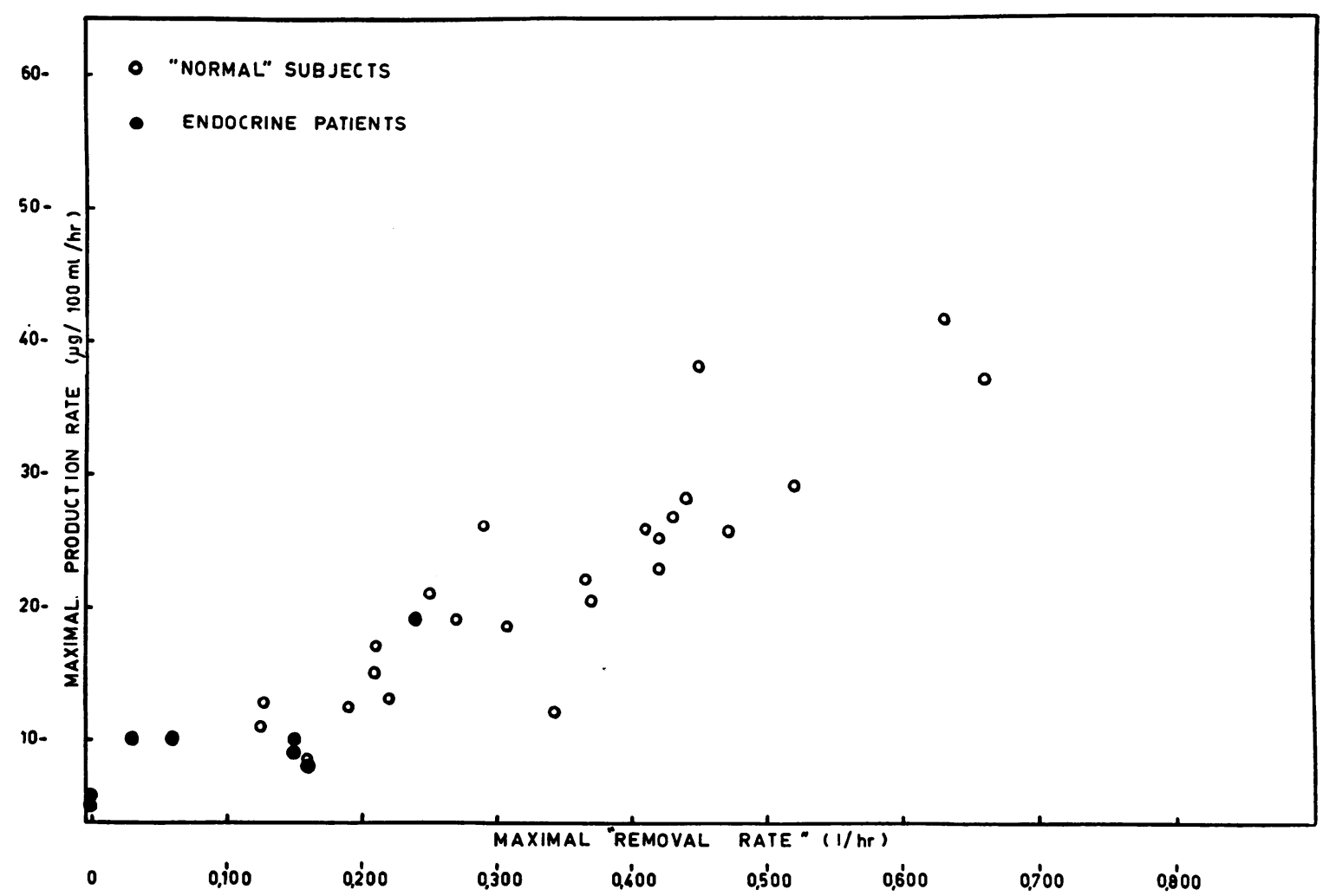

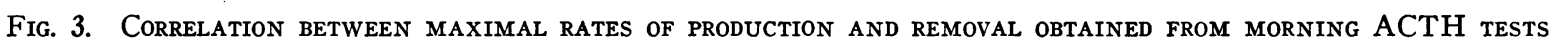
IN NORMAL AND IN ENDOCRINE CASES.

The obtained plasma corticoid values have been analyzed by means of an electronic analog computer.

In about two-thirds of the cases it could be shown that the curves of corticoid values were determined by a constant maximal rate of production and maximal rate of removal. However, in 7 out of 92 cases, production and removal did not remain constant but both decreased steadily with time.

Production rate and removal rate could be calculated for each ACTH curve independently from data obtained by cortisol infusion experiments. Removal rate, as calculated from ACTH infusion, was always greater than that measured from cortisol administration.

Changes in production and removal during ACTH infusions at different times of the day have also been investigated. The production rate during night tests was greater than that in morning and evening tests. The removal rate calculated from the ACTH tests with the analog computer was not constant throughout the day but was greater during the evening and at night than during the morning. Removal rates obtained from cortisol infusions also did not remain constant throughout the day. Rates of production and removal of steroids during ACTH infusion were maximal. Evaluations of diurnal variation in real production or real removal of corticoids by the adrenal cortex on the basis of these parameters are of questionable validity.

A reciprocal relationship appears to exist between "maximal" production rate and "maximal" removal rate.

\section{ACKNOWLEDGMENT}

We are grateful to Dr. P. Osinski for his help in designing and performing the isotopic dilution experiments. The ACTH used in this work was donated by Wilson.

\section{REFERENCES}

1. Brown, H., Willardson, D. G., Samuels, L. T., and Tyler, F. H. 17-Hydroxycorticosteroid metabolism in liver disease. J. clin. Invest. 1954, 33, 1524. 
2. Eik-Nes, K., Sandberg, A. A., Tyler, F. H., and Samuels, L. T. Plasma levels of 17-hydroxycorticosteroids following the administration of adrenal steroids. Acta endocr. (Kbh.) 1955, 18, 244.

3. Samuels, L. T. Effect of aging on the steroid metabolism as reflected in plasma levels in Hormones and the Aging Process. New York, Academic Press, 1956, p. 21.

4. Samuels, L. T., Brown, H., Eik-Nes, K., Tyler, F. H., and Dominguez, O. V. Extra-adrenal factors affecting the levels of 17 -hydroxycorticosteroids in plasma. Ciba Found. Coll. Endocr. 1957, 11, 208.

5. De Moor, P., Steeno, O., Raskin, M., Hendrikx, A., and De Tremerie, E. Fluorimetrische bepaling der biologisch-actieve 11-hydroxycorticosteroiden in het plasma-Enkele bemerkingen over de dynamiek der bijnierschorsfunktie. Verhandelingen van de Koninklijke Vlaamse Academie voor Geneeskunde van België 1959, 18, 368.

6. De Moor, P., Steeno, O., Raskin, M., and Hendrikx, A. Fluorimetric determination of free plasma 11hydroxycorticosteroids in man. Acta endocr. (Kbh.) 1960, 33, 297.

7. Borth, R. Steroids in human blood. Vitam. and Horm. 1957, 15, 259.
8. Bush, I. E. Methods of paper chromatography of steroids applicable to the study of steroids in mammalian blood and tissues. Biochem. J. 1952, 50, 370.

9. Peterson, R. E., Karrer, A., and Guerra, S. L. Evaluation of Silber-Porter procedure for determination of plasma hydrocortisone. Analyt. Chem. 1957, 29, 144.

10. Sayers, G., Glenn, E. M., Sydnor, K. L., Lipscomb, M., Sweat, M. L., Kelly, L. W., Jr., Levy, R. P., and Jefferies, W. McK. Plasma and urinary steroids after hydrocortisone infusion. J. clin. Invest. 1955, 34, 1600.

11. Upton, G. V., and Bondy, P. K. The binding of cortisol by plasma protein. Arch. Biochem. 1958, 78, 197.

12. Migeon, C. J. Cortisol production and metabolism in the neonate. J. Pediat. 1959, 55, 280.

13. Peterson, R. E. The miscible pool and turnover rate of adrenocortical steroids in man. Recent Progr. Hormone Res. 1959, 15, 231.

14. Perkoff, G. T., Eik-Nes, K., Nugent, C. A., Fred, H. L., Nimer, R. A., Rush, L., Samuels, L. T., and Tyler, F. H. Studies of the diurnal variation of plasma 17-hydroxycorticosteroids in man. J. clin. Endocr. 1959, 19, 432.

\section{SPECIAL NOTICE TO SUBSCRIBERS}

Post Offices will no longer forward the Journal when you move.

Please notify The Journal of Clinical Investigation, Business

Office, 333 Cedar Street, New Haven 11, Conn., at once when you have a change of address, and do not omit the zone number if there is one. 